\title{
A Study of Prospective Teachers' Consumption Patterns on Special Days
}

\author{
Halil İbrahim Sağlam \\ Faculty of Education, Sakarya University, Turkey
}

Copyright $(2016$ by authors, all rights reserved. Authors agree that this article remains permanently open access under the terms of the Creative Commons Attribution License 4.0 International License

\begin{abstract}
The purpose of this study was to identify prospective teachers' consumption patterns on special days. The sample was comprised of 29 prospective teachers (22 females and 7 males) who studied Primary School Teaching in the Faculty of Education at Sakarya University during the 2014-2015 Academic Year. The study was designed as a phenomenological one, a qualitative research design. The data were collected with a semi-structured interview form, a qualitative data collection instrument. The interview form consisted of two parts. The first one contained questions as to descriptive information about the prospective teachers while the second was intended for the identification of their views on their consumption patterns on special days. The content validity of the questions was examined by three specialists, and they were revised in accordance with their recommendations. In addition, the comprehensibility of the questions was tested by five prospective teachers, and the form was finalized. The data were subject to content analysis. The results showed that the great majority of the prospective teachers $(90 \%)$ considered Mother's Day, Father's Day, Valentine's Day and birthdays to be special days. Furthermore, $69 \%$ of them regarded shopping on special days as meaningful.
\end{abstract}

Keywords Consumption Patterns, Special Days, Valentine's Day, Mother's Day, Prospective Teachers

\section{Introduction}

In today's modern consumption societies, the emotional dimension of consumption is becoming more important. The symbolic meaning of products and brands has been one of the most important tools in gaining competitive advantage. Consumers are not merely seen as rational problem solvers who try to find maximum benefit in their problems. They try to enjoy their consumption experience as well as meeting their needs [1]. Shopping for today's customers who live in a busy tempo of life, is a way of spending free time and having fun. Shopping is considered as not only an action which is essential to buy the needs but also a way to make the free time worthy together with the family or friends. Sellers and advertisers who are aware of that description of today's people have thematic parks, which have been designed as private life fields and have changed the fact of shopping to a life style [2]. By means of many factors such as increase of the revenue, plenty of leisure time, advancement of technology, online shopping etc., the style of consumers' purchasing has changed. It is seen that many consumers do impulse shopping due to the consumer's time pressure and the situational factors in shopping center. The feeling pleasure of doing shopping is also one of the most significant factors in consumers' purchasing behaviors and also this sensation is considered as non-negligible fact about impulse shopping [3]. Shoppers potentially can engage in hedonic consumption to satisfy approach needs, such as seeking excitement, as well as to satisfy avoidance needs, such as escaping to a fantasy world of shopping [4].

Despite worldwide attempts to tackle starvation, the consumption frenzy is becoming more and more prevalent, and occasions such as Mother's Day, Father's Day, Teacher's Day, Valentine's Day and birthdays are abused in this respect. This is despite the fact that we have to satisfy infinite requirements with finite resources, prioritize basic requirements when purchasing things, and overcome extravagance [5]. Needless to say, the exchange of gifts is a natural way of remembering or being remembered. It can also be argued that remembering mothers, fathers and teachers, all of whom play a special and significant role in our lives, will help raise awareness. However, marketing people abuse these special days in order to initiate and maintain high levels of consumption, which is something to reflect on from a conscious consumer's viewpoint.

In a consumption based society, the continuity of production relies on increases in consumption. In this respect, special occasions such as Mother's Day and Father's Day, which were created by the West in cooperation with the media, seem to be abused in an attempt to boost consumption [6,7]. One of these days is Valentine's Day, which is celebrated in many parts of the 
world. It is on this day that the consumption frenzy reaches its peak. Apparently, there are no limits on gifts, preparations and celebrations that are intended for the opposite sex or one's beloved [8]. Consumers, do not shop only to fill their needs, but at the same time they enjoy the consumption experience [9]. Such special days provide an opportunity of loots for marketing people, who well know that the exchange of gifts makes people happy.

It is argued that marketing people abuse Mother's Day, Father's Day, Teacher's Day, Valentine's Day and birthdays to make consumption more and more popular, since the exchange of gifts, though regarded as an obligation, satisfy both the giver and the receiver [10], the price and brand of the gift suggests the degree of value placed on the relationship between the giver and the receiver [11], and gifts have a symbolic meaning in forming social relationships and help people give meaning to certain days [12]. It is essential to reveal the consumption patterns of prospective teachers, who are responsible for teaching their future students to become conscious consumers, on special days. Therefore, the purpose of this study is to identify prospective teachers' consumption patterns on special days. For this purpose, answers to the following questions will be sought:

1. What are the views of the prospective teachers about whether Mother's Day, Father's Day, Teacher's Day, Valentine's Day and birthdays are special days or not?

2. What are the views of the prospective teachers about shopping on special days?

3. What are the views of the prospective teachers about the meaningfulness of shopping on special days?

\section{Materials and Methods}

The study was designed as a phenomenological one, a qualitative research design. Phenomenological studies generally attempt to reveal and interpret individual perceptions of or perspectives on a certain phenomenon [13].

\subsection{Sample}

Convenience sampling method was used for selection. In the first stage, 61 prospective teachers had asked for attending the study but only 29 of them were accepted to attend. Therefore, the sample was comprised and limited of 29 prospective teachers (22 females and 7 males) who studied Primary School Teaching in the Faculty of Education at Sakarya University during the 2014-2015 Academic Year.

\subsection{Data Collection Instrument}

First, the literature was reviewed, and a semi-structured interview form was developed on the basis of previous research. The questions in the form were designed in a way that would reveal the prospective teachers' consumption patterns on special days. The content validity of the questions was examined by three specialists, and they were revised in accordance with their recommendations. In addition, the comprehensibility of the questions was tested by five prospective teachers, and the form was finalized. The following questions were involved in the interview form: Do you consider Mother's Day, Father's Day, Teacher's Day, Valentine's Day and birthdays to be special days (1), On which of the following days do you shop: Mother's Day, Father's Day, Teacher's Day, Valentine's Day and birthdays (2), What does shopping on Mother's Day, Father's Day, Teacher's Day, Valentine's Day and birthdays mean to you (3)?

\subsection{Data Analysis}

In phenomenological studies, data analysis is intended for revealing lives and meanings. Accordingly, it attempts to conceptualize data and generate themes that can define the phenomenon at issue. For this study, the data were subject to content analysis. The primary objective of content analysis is to arrive at concepts and relationships that can account for collected data. It is necessary to generate themes that can basically account for data on the basis of codes and that can group codes under particular categories. The first step of thematic coding is to identify similarities and dissimilarities between emerging codes and to generate themes that can bring connected codes together [13]. The data were separately examined and coded by the specialists, and the coding consistency was 0.86 . Direct quotations were included in the presentation of the results. Each of the prospective teachers was assigned a code number ranging from 1 to 29. For instance, C1 stood for Prospective Teacher 1 just as C2 represented Prospective Teacher 2.

\section{Findings}

The generated themes and codes were presented in this section, and direct quotations from the prospective teachers were included.

Table 1. The views of the prospective teachers on whether they considered Mother's Day, Father's Day, Teacher's Day, Valentine's Day and birthdays to be special days

\begin{tabular}{cc}
\hline Whether special or not & $\mathrm{n}$ \\
\hline Special & 26 \\
Not special & 3 \\
Total & 29 \\
\hline
\end{tabular}

The great majority of the prospective teachers $(n=26)$ considered Mother's Day, Father's Day, Teacher's Day, Valentine's Day and birthdays to be special days while $10 \%$ of them $(n=3)$ did not regard them as special (Table 1). 
Table 2. The views of the prospective teachers on shopping on special days

\begin{tabular}{ccc}
\hline Themes & Codes & $\mathrm{n}$ \\
\hline \multirow{3}{*}{ Special Days } & Birthdays & 24 \\
& Mother's Day & 20 \\
& Father's Day & 14 \\
& Valentine's Day & 7 \\
& Teacher's Day & 6 \\
\hline
\end{tabular}

Table 2 presents the views of the prospective teachers on the theme special days. The following quotations are all examples of their ideas on the theme: "I may shop on all these special days except for Valentine's Day [C1]." "I shop on Valentine's Day, Mother's Day, Father's Day and birthdays of my friends or relatives [C2]." "I shop on Mother's Day, Father's Day, Teacher's Day and birthdays [C3]." "I shop to a slight degree on Mother's Day, Father's Day and birthdays [C4]." "On Mother's Day and Valentine's Day. I would like to please my dearie Valide Sultan (meaning the sultan's mother), who has raised me up to now, and to make her face wreathed in smiles [C6]." "On Valentine's Day, birthdays, Mother's Day and Father's Day [C7]." "I shop on Valentine's Day, often on Mother's Day and birthdays [C8]." "I spend money mostly on birthdays of my friends [C9]." "I shop on Mother's Day, Father's Day and birthdays [C11]." "I shop on Mother's Day, Father's day and birthdays [C13]. "I shop on Mother's Day, Father's Day, birthdays and Teacher's Day [C14]." "I like shopping on Mother's Day, Father's Day, Teacher's Day and my own birthday [C15]." "I invariably buy a gift for my mother on Mother's Day [C16]." "I shop on all of the special days [C17]." "I generally shop on birthdays [C18]. "I generally shop on birthdays [C19]." "I shop on Mother's Day and birthdays [C20]." "I shop on Mother's Day, Father's Day and birthdays [C21]. "I shop on all of them; special days are important [C22]." "I shop on some birthdays [C23]." "I only shop on birthdays. I buy gifts for my friend and myself [C24]." "I shop on Valentine's Day, birthdays and Mother's Day [C25]." "I shop on birthdays and Mother's Day [C26]." "I shop on birthdays, Mother's Day and Father's Day [C27]." "I only place value on birthdays, but instead of shopping, I would like to prepare something myself [C28]." "I buy gifts for people I love on birthdays, Mother's Day and Father's Day [C29]."

Table 3. The views of the prospective teachers on the meaningfulness of shopping on special days

\begin{tabular}{ccc}
\hline Themes & Codes & $\mathrm{n}$ \\
\hline \multirow{3}{*}{ Meaningful } & To make one happy, to please one & 14 \\
& To meet the expectation & 2 \\
& To make one feel the given value & 4 \\
Meaningless & It is meaningless & 7 \\
& It targets consumption & 2 \\
\hline
\end{tabular}

Table 3 classifies the views of the prospective teachers on the significance of shopping on special days as two themes, namely meaningful and meaningless. The following quotations are from those participants who regarded shopping on special days as meaningful: "Making my mother happy even with a small gift makes me happy, too [C1]." "Describing these days as special makes people have expectations knowingly or unknowingly. I shop on these days with the primary purpose of not failing to meet the expectation and make the person happy [C2]." "Shopping for my mother on Mother's Day makes me really happy. I take pride in knowing that she will be happy [C3]." "It means pleasing the other person (my mother or my girlfriend on Valentine's Day if we are serious about each other) [C6]." "It makes you proud when people you prize smile and become happy because of you [C7]." "I believe that these days are more special. One can make the best of these opportunities to make people he/she likes happy [C8]." "Though I don't think these days are very important, it makes me happy to shop for people I like. Seeing that the person who gets the gift will also be happy, it is very meaningful to buy small gifts on these important days [C11]." "I don't think they are meaningless just because they are special on these days. They are valuable to us every day. But people all around the world experience the same feeling [C13]." "We make the person feel that he/she is valuable to us [C14]." "I like shopping on Mother's Day. That is because I want to make my mother happy [C15]." "To bliss the person I like out [C17]." "Since it will make the person for whom we will buy a gift happy, I will be happy to buy a gift, too [C18]." "I don't hesitate to shop if the person is valuable to me. I generally shop [C20]." "I make myself happy by making the other person happy [C22]." "I like giving others gifts and making them happy, and this makes me happy, too [C24]." "Special. Needs attention [C25]." "This day is very important to me, since it makes me happy to buy gifts for people I like and to see their happiness [C26]." "It is primarily out of obligation [C27]." "It pleases me to buy a gift for my mother on Mother's Day and to make her happy [C29]."

The following quotations are from those participants who regarded shopping on special days as meaningless: "The public image of these days is that it is the custom to shop on these days, or this image is an illusion brought about by the commercial system. You are sometimes forced to buy gifts not to be alienated from the society [C5]." "It seems meaningless to confine them to one single day. I don't buy a gift for my mother on one day of the year because she is always my mother [C9]." "They don't mean anything. It is rather meaningless to remember our mothers and buy gifts only on one single day [C10]." "They don't mean anything, because I do not shop on these days [C12]." "Except for Mother's Day, these days seem to be an imposition and shopping traps. But I don't see it as an obligation because I love my mother very much. I am against special days [C16]." "They don't mean much [C19]." "I find it unnecessary to celebrate them every year [C21]." "I can't spare much time for shopping on special days [C23]." "They mean nothing. I have never thought it is a sensible thing to do [C28]." 


\section{Conclusion and Discussion}

The results showed that the great majority of the prospective teachers $(90 \%)$ considered Mother's Day, Father's Day, Valentine's Day and birthdays to be special days, and only a small percentage of them (10\%) did not regard them as special. Furthermore, $69 \%$ of them regarded shopping on special days as meaningful while $31 \%$ of them found it meaningless. In their study, Kazancoglu and Aytekin [8] found that consumers buy gifts on Valentine's Day mostly for their beloved or spouses. Goodwin, Smith \& Spiggle [14] maintain that young men spend more money on Valentine's Day and that especially women expect to be given a gift and think men have to buy one. Yeygel-Çakır, Temel-Eğinli \& Okat- Özdem [3] found big shopping centers have become the places where free time is spent besides consumption and are considered as the places where the customers can have fun and socializing in their study. As shown in the findings, prospective teachers mostly prefer "to make one happy, to please one" while shopping in special days. It is caused by the reason that they may have fun and socializing tendency. In that case, results of this study show similar results compared to Yeygel-Çakır, Temel-Eğinli \& Okat-Özdem [3]. Öz \& Mucuk [1] found of the research, it is determined that there is an undeniable effect of hedonic consumption on impulse shopping. Uygun, Mete and Güner [15] emphasis that hedonic shopping motivations become prominent. In their study on male consumers, Otnes, Ruth \& Milbourne [16] discovered that male consumers have mixed feelings about the experience of exchanging gifts, namely affection, pleasure, disappointment, guilt and anger. Rugimbana, Donahay, Neal \& Polonsky [17] concluded that the strongest motivation for young men to buy gifts on Valentine's Day is obligation. Babacan [18] holds that shopping on special days like New Year's Day or Valentine's Day makes people happy, causing them to overspend and make impulse purchases. These results suggest that special days lead people to spend more than their budget allows.

\section{REFERENCES}

[1] Öz, M. \& Mucuk, S. (2015). Tüketici satınalma davranış1 kapsamında hedonic tüketimin plansız alışveriş üzerindeki etkisinin incelenmesi. Pazarlama Teorisi ve Uygulamalarl Dergisi, 1(2), 37-60.

[2] Ünal, S. ve Ceylan, C. (2008). Tüketicileri hedonik alişverişe yönelten nedenler: İstanbul ve Erzurum illerinde karşilaştirmali bir araştırma. İktisadi ve İdari Bilimler Dergisi, $22(2), 265-283$

[3] Yeygel-Çakır, S., Temel-Eğinli, A. \& Okat-Özden, Ö. (2006).
Hediye verme davranışı ve alışveriş merkezlerinde deneyim yaratma stratejileri: Sevgililer günü örneği. İletişim Araştırmaları Dergisi, 4(1), 97-120.

[4] Arnold, M. J. \& Reynolds, K. E. (2012). Approach and Avoidance Motivation: Investigating Hedonic Consumption in a Retail Setting. Journal of Retailing, 88, 399-411.

[5] Sağlam, H. İ. (2010). İlköğretim öğrencilerinin bilinçli tüketicilik düzeylerinin çeşitli değişkenler açısından incelenmesi. Kuram ve Uygulamalarda Eğitim Bilimleri Dergisi, 10 (4), 2531-2568.

[6] Erkal, M. (1983). Sosyoloji. İstanbul: Filiz Kitabevi.

[7] Bayhan, V. (2011). Tüketim toplumunda bireyin ontolojik mottosu: Tüketiyorum öyleyse varım. Sosyoloji Konferansları Dergisi, 43, 221-248.

[8] Kazançoğlu, İ. ve Aytekin, P. (2014). Sevgililer günü ritüellerinin alışveriş deneyimi ve hazcı alışveriş değerine etkisi: Alışveriş merkezlerinde bir uygulama. Uluslararası Yönetim İktisat ve İşletme Dergisi, 10 (22), 67-93.

[9] Eken, İ. ve Yazıcı, M. (2015). Hedonizmin satınalma davranışlarına etkileri: Çevrimiçi alışverişlerde kadın akademisyenler. İstanbul Üniversitesi İletişim Fakültesi Dergisi,48, 67-90

[10] Qian, W., Razzaque, M. A. \& Keng, K. A. (2007). Chinese Cultural Values and Gift-Giving Behavior. Journal of Consumer Marketing, 24(4), 214-228.

[11] Solomon, M. R. (1983). The role of products as social stimuli: A symbolic interactionism perspective. Journal of Consumer Research 10, 319-329.

[12] Sherry, J. F. (1983). Gift Giving in Anthropological Perspective. Journal of Consumer Research 10: 157-168.

[13] Yıldırım, A. ve Şimşek, H. (1999). Sosyal Bilimlerde Nitel Araştırma Yöntemleri. Ankara: Seçkin Yayınevi.

[14] Goodwin, C., Smith, K. L. \& Spiggle, S. (1990). Gift giving: consumer motivation and the gift purchase process. In M. Goldberg, G. Gorn, R. Pollay (Eds.), Advances in Consumer Research (17, pp. 690-698). Provo, UT: Association for Consumer Research.

[15] Uygun, M., Mete, S. ve Güner, E. (2014). Tüketicilerin alışveriş motivasyonları ile ağızdan ağıza iletişim davranışları arasındaki ilişkiler. Organizasyon ve Yönetim Bilimleri Dergisi, 6(1), 35-56.

[16] Otnes, C., Ruth, J. A., \& Milbourne, C. C. (1994). The pleasure and pain of being close: men's mixed feelings about participation in valentine's day gift exchange. Advances in Consumer Research, January, 21(1), 159-164.

[17] Rugimbana, R., Donahay, B., Neal, C., \& Polonsky, M. J. (2003). The role of social power relations in gift giving on Valentine's Day. Journal of Consumer Behaviour, 3(1), 6373 .

[18] Babacan, M. (2001). Hedonik tüketim ve özel günler alışverişlerine yansıması. 6. Ulusal Pazarlama Kongresi, Erzurum. 